\title{
Application of the Vogel Approximation Method to Reduce Transport-logistics Processes
}

\author{
Martina Hlatká ${ }^{1, *}$, Ladislav Bartuška ${ }^{1}$, and Ján Ližbetin ${ }^{1}$ \\ ${ }^{1}$ Institute of Technology and Business in České Budějovice, Faculty of Technology, 37001 České \\ Budějovice, Czech Republic
}

\begin{abstract}
The article deals with logistics processes in companies. Logistics aims to optimize material, finance and information flows to optimize overall costs in companies. The first part of the article describes the methods by means of which the processes in companies can be optimized, namely the Vogel approximation method. In the second part of the article, the method is implemented in a particular manufacturing company with the result of distribution route optimization and reduction of operating costs of transport.
\end{abstract}

\section{Introduction}

Logistics has undergone a major change in recent decades. Unlike in previous years, today it deals with the flow of material, information and financial resources in all areas of a company. This implies that logistics does not only deal with material flow in individual businesses, but also assesses individual influences from time, place and space point of view in order to satisfy customers and achieve optimal costs associated with these activities. It is a comprehensive science which improves corporate processes and enables the company to respond more quickly to market and customer demands. Nowadays, the emphasis is placed on the quality and high level of services provided; thus, the use of logistics is a necessity.

In general, optimizations are increasingly used as their results bring proposals for improving processes in companies. The advantage of optimization analyses is cost reduction. In addition to economic improvement, there is also shortening of travelled routes, which is also associated with a reduction in the time required to carry out activities. The aim of such an optimization is the most efficient use of means of transport, technology, and human resources with regard to reducing economic costs [1-4]. Currently, there are many ways to optimize processes in a company. The most commonly used are those using operational research methods or graphical representations [4-6].

\section{Methods}

The Vogel approximation method deals with finding an optimal solution taking into account the relationships of price indices. This method compares always the two lowest

*Corresponding author: hlatka@mail.vstecb.cz 
price indices in both a column and a row. Using these comparisons, which are called differences, the task is to evaluate a field whose "inoccupation" by the cheapest option would have the worst impact on the overall result.

In the procedure of the Vogel approximation method, the differences between two smallest rates for each row and column are first counted. The individual differences are written outside the table. For each row, the value is written to the left of the table and for each column the value is written below the table. Subsequently, the highest of the calculated differences is selected, which now indicates the area for the next calculation step. The next step is to find a field with the lowest rate in the selected area, i.e. column or row. We put the highest value in this cell. The maximum value is derived from the restrictive conditions normally written in the last column and row of the assembled matrix.

In this research, the modified version of the Vogel approximation method is fundamental. This method does not take into account restrictive capacities and rates. The purpose of the modified version calculation is to find the shortest distance which enables completing the transport task.

The first step in this research is to adjust the distance matrix that was assembled during the previous method. The change takes place on the main diagonal, where zero values are located. These zero values will be changed to X. Since there is no capacity limitation in the specified delivery routes, the two lowest values of the distance are searched in each column and row. The difference is calculated from the two smallest values. This difference is then written outside the table the same way as in the normal method. The steps are performed for all columns and rows, and the difference with the highest value is selected from the calculated differences. In contrast to the usual Vogel approximation method, where the lowest rate would now be selected and the maximum under the restrictive conditions would be added, a cell with the lowest value of distance is chosen in the selected area. This procedure is repeated until the entire transport task is complete [5-8].

\subsection{Input values}

The application of the Vogel approximation method will be carried out in a meat and sausage company. It is a small family business, where the optimization of the transportlogistic processes has not yet been dealt with. Based on the interview with the owner of the company it was possible to analyse essential data necessary for the compilation of a detailed list of current stopping points which the company serves by its own internal transport. The first task is to compile a detailed list of stops that will include the exact addresses where the goods will be delivered. Subsequently, the task is to optimize the original routes. Deliveries of goods are always on weekdays, i.e. from Monday to Friday. Each day of the week has more or less modified route. The Friday delivery route was selected for the application of the method. On Friday, the goods are unloaded only six times. This short route is 64.9 kilometres.

Table 1. Places of unloading on Friday. Source: authors

\begin{tabular}{|l|l|l|}
\hline & Town & Address \\
\hline $\mathbf{V}_{\mathbf{1}}$ & Volduchy & Volduchy $63 ; 338$ 22; Volduchy \\
\hline $\mathbf{V}_{\mathbf{2}}$ & Chrást & Dlouhá 481; 330 03; Chrást \\
\hline $\mathbf{V}_{\mathbf{3}}$ & Chrást & Tř. Čs. Odboje $111 ; 33003 ;$ Chrást \\
\hline $\mathbf{V}_{\mathbf{4}}$ & Plzeň & Sladkovského $660 / 34 ; 32600 ;$ Plzeň 2 \\
\hline $\mathbf{V}_{\mathbf{5}}$ & Plzeň & Kř́imická $927 / 48 ; 31800 ;$ Plzeň 3 \\
\hline $\mathbf{V}_{\mathbf{6}}$ & Plzeň & Domažlická $182 / 13 ; 31800 ;$ Plzeň 3 \\
\hline $\mathbf{V}_{\mathbf{7}}$ & Plzeň & U letiště $1074 / 2 ; 30100 ;$ Plzeň 3 \\
\hline
\end{tabular}


The normal version of the Vogel approximation method takes into account limited capacity. Each cell typically contains a certain rate. A difference is made between the two smallest rates in the row and it is then written at the edge of the row; the same is done in the columns. Then the highest value from the rate differences is found. According to the value, the row or column in which the lowest rate is found is determined. This procedure is repeated until the transport task reaches the optimum result [9].

The modified Vogel approximation method does not include rates and limited capacity. The matrix only uses the distances of individual points. Thus, in doing the transport task, the difference between the two smallest distances in the row is first sought $[10,11]$. The same procedure is repeated for the other rows and columns, where the difference is always written behind the prepared matrix. The highest value is selected from the differences and it determines the selected column or row, from which the smallest value determining the distance is selected. This value is highlighted in light green in the table.

Now, there is another change compared to the normal Vogel approximation method. Instead of occupying only one cell, it is necessary to cross out the entire row and column in which the calculation procedure is located. This step is important in order to effectively calculate such a route that will serve all scheduled stop points. The unloading place, where the transport task is located, is marked in yellow in the table. In addition, it is necessary to eliminate the possibility of more routes. It is necessary to remove such a point, which would early complete the transport task. If two identical values are found, it is purely a matter of choice which option will be chosen for the next calculation step. Subsequently, the procedure is repeated-from the recalculation of differences to crossing out unnecessary cells [12-17].

\section{Results}

\subsection{Vogel approximation method - Friday distribution route}

To clarify the process of the modified version of the Vogel approximation method, the task begins with calculating the smallest matrix of distances, and thus the shortest calculation of the whole week as well. The smallest distance matrix occurs for day delivery on Friday. This matrix has the dimensions of $7 \times 7$ cells, so the clear explanation of the procedure will be the most transparent on this matrix $[16,17]$.

Table 2. Friday - VAM - Modification 1. Source: authors

\begin{tabular}{|c|c|c|c|c|c|c|c|c|}
\hline & $V_{1}$ & $V_{2}$ & $V_{3}$ & $V_{4}$ & $V_{5}$ & $V_{6}$ & $V_{7}$ & \\
\hline$V_{1}$ & $X$ & 10.7 & 11.5 & 22.1 & 24.4 & 29.2 & 25.9 & 0.8 \\
\hline$V_{2}$ & 10.7 & $\mathrm{X}$ & 1.0 & 12.0 & 14.3 & 19.0 & 15.7 & 9.7 \\
\hline$V_{3}$ & 11.5 & 1.0 & $\mathrm{X}$ & 11.0 & 13.3 & 18.0 & 14.8 & 10.0 \\
\hline$V_{4}$ & 22.2 & 11.7 & 10.7 & $X$ & 4.0 & 7.9 & 4.7 & 0.7 \\
\hline$V_{5}$ & 24.9 & 14.4 & 13.4 & 3.9 & $X$ & 7.3 & 4.7 & 0.8 \\
\hline$V_{6}$ & 24.7 & 14.2 & 13.3 & 3.8 & 1.9 & $X$ & 4.6 & 1.9 \\
\hline $\mathbf{V}_{7}$ & 26.3 & 15.8 & 14.8 & 4.8 & 4.8 & 4.2 & $\mathrm{X}$ & 0.6 \\
\hline & 0.8 & 9.7 & 9.7 & 0.1 & 2.1 & 3.1 & 0.1 & \\
\hline
\end{tabular}

In the first step of the calculation, it is necessary to find the differences in the smallest distance values in each row and in each column. The values of individual differences are then written outside the table. In the first row $V_{1}$ we calculate the difference of values for cells $\left[\mathrm{V}_{1} ; \mathrm{V}_{3}\right]=11.5 \mathrm{~km}$ and $\left[\mathrm{V}_{1} ; \mathrm{V}_{2}\right]=10.7 \mathrm{~km}$. The difference of these values is 0.8 kilometres, which is written in the right-hand outer part of the table [5, 18]. 
The second step is to select the highest value of all the differences. In the table, this value is highlighted in yellow. The highest distance difference is 10.0 kilometres, located in row $\mathrm{V}_{3}$. As a result of this step it is determined that the selection of the smallest distance in row $\mathrm{V}_{3}$ follows. This value is based in cell $\left[\mathrm{V}_{3} ; \mathrm{V}_{2}\right]=1.0 \mathrm{~km}$ and is highlighted in yellow inside the table.

This is followed by crossing out values that would untimely complete the transport task or would pose a multi-ring problem. It begins by crossing out all the values in the row and the column in which the calculation is located. A provisional route is $\mathbf{V}_{\mathbf{3}} \rightarrow \mathbf{V}_{\mathbf{2}}$ for the time being. It is necessary to avoid cycling of this route. Therefore, the value located in cell $\left[\mathrm{V}_{2}\right.$; $\left.\mathrm{V}_{3}\right]$ is crossed out as well $[5,6,19]$.

Table 3. Friday - VAM - Modification 2. Source: authors

\begin{tabular}{|c|c|c|c|c|c|c|c|c|c|}
\hline & $V_{1}$ & $V_{2}$ & $V_{3}$ & $V_{4}$ & $V_{5}$ & $V_{6}$ & $V_{7}$ & \multirow[b]{2}{*}{0.8} & \multirow[b]{2}{*}{10.6} \\
\hline$V_{1}$ & $X$ & 10.7 & 11.5 & 22.1 & 24.4 & 29.2 & 25.9 & & \\
\hline$V_{2}$ & 10.7 & $\mathrm{X}$ & 1.0 & 12.0 & 14.3 & 19.0 & 15.7 & 9.7 & 1.3 \\
\hline$V_{3}$ & 11.5 & 1.0 & $X$ & 11.0 & 13.3 & 18.0 & 14.8 & 10.0 & $X$ \\
\hline$V_{4}$ & 22.2 & 11.7 & 10.7 & $\mathrm{X}$ & 4.0 & 7.9 & 4.7 & 0.7 & 0.7 \\
\hline$V_{5}$ & 24.9 & 14.4 & 13.4 & 3.9 & $X$ & 7.3 & 4.7 & 0.8 & 0.8 \\
\hline$V_{6}$ & 24.7 & 14.2 & 13.3 & 3.8 & 1.9 & $\mathrm{X}$ & 4.6 & 1.9 & 1.9 \\
\hline$V_{7}$ & 26.3 & 15.8 & 14.8 & 4.8 & 4.8 & 4.2 & $\mathrm{X}$ & 0.6 & 0.6 \\
\hline & 0.8 & 9.7 & 9.7 & 0.1 & 2.1 & 3.1 & 0.1 & & \\
\hline & 11.5 & X & 0.8 & 0.1 & 2.1 & 3.1 & 0.1 & & \\
\hline
\end{tabular}

The procedure is repeated in the second step. First, differences of the smallest values for the rows and columns are calculated. There is nothing to subtract for row $\mathrm{V}_{3}$ row and column $\mathrm{V}_{2}$ anymore, so the position outside the table is replaced by $\mathrm{X}$. After calculating the differences, the highest value is selected, i.e. 11.5 below column $\mathrm{V}_{1}$. This determines the column from which the lowest possible value is selected. This value is 10.7 kilometres located in the cell with coordinates $\left[\mathrm{V}_{2} ; \mathrm{V}_{1}\right]$.

Then the entire column and row of the above mentioned cell are crossed out. Due to the possibility of early completion of the transport task, it is necessary to check such cell values that would untimely return the calculation to the previous places of unloading without servicing all the specified delivery unloading places. The provisional route is as follows: $\mathbf{V}_{\mathbf{3}}$ $\rightarrow V_{2} \rightarrow V_{1}$. It is necessary to avoid early closure of the route from $V_{1}$ to $V_{3}$. Therefore, it is necessary to have the value in cell $\left[\mathrm{V}_{1} ; \mathrm{V}_{3}\right]$ also crossed out $[5,6,20]$.

Table 4. Friday - VAM - Modification 3. Source: [authors]

\begin{tabular}{|c|c|c|c|c|c|c|c|c|c|c|}
\hline & $V_{1}$ & $V_{2}$ & $V_{3}$ & $V_{4}$ & $V_{5}$ & $V_{6}$ & $V_{7}$ & \multirow[b]{2}{*}{0.8} & \multirow[b]{2}{*}{10.6} & \multirow[b]{2}{*}{2.3} \\
\hline$V_{1}$ & $\mathrm{X}$ & 10.7 & 11.5 & 22.1 & 24.4 & 29.2 & 25.9 & & & \\
\hline$V_{2}$ & 10.7 & $\mathrm{X}$ & 1.0 & 12.0 & 14.3 & 19.0 & 15.7 & 9.7 & 1.3 & $X$ \\
\hline$V_{3}$ & 11.5 & 1.0 & $X$ & 11.0 & 13.3 & 18.0 & 14.8 & 10.0 & $X$ & $X$ \\
\hline$V_{4}$ & 22.2 & 11.7 & 10.7 & $\mathrm{X}$ & 4.0 & 7.9 & 4.7 & 0.7 & 0.7 & 0.7 \\
\hline$V_{5}$ & 24.9 & 14.4 & 13.4 & 3.9 & $\mathrm{X}$ & 7.3 & 4.7 & 0.8 & 0.8 & 0.8 \\
\hline$V_{6}$ & 24.7 & 14.2 & 13.3 & 3.8 & 1.9 & $X$ & 4.6 & 1.9 & 1.9 & 1.9 \\
\hline$V_{7}$ & 26.3 & 15.8 & 14.8 & 4.8 & 4.8 & 4.2 & $X$ & 0.6 & 0.6 & 0.6 \\
\hline & 0.8 & 9.7 & 9.7 & 0.1 & 2.1 & 3.1 & 0.1 & & & \\
\hline & 11.5 & $X$ & 0.8 & 0.1 & 2.1 & 3.1 & 0.1 & & & \\
\hline & X & $X$ & 2.6 & 0.1 & 2.1 & 3.1 & 0.1 & & & \\
\hline
\end{tabular}

After the second modification, it is necessary to evaluate the differences in the rows and columns. The completely crossed out rows $\mathrm{V}_{2}$ and $\mathrm{V}_{3}$ are omitted. In addition, the differences of the smallest values in columns $V_{1}$ and $V_{2}$ are not counted. The highest value of all calculated differences is 2.6 , which is located in column $V_{3}$. On account of this, the 
lowest distance in column $\mathrm{V}_{3}$ is sought. The result is $10.7 \mathrm{~km}$. This cell is yellow in the table again. The provisional route calculated by the modified version of the Vogel approximation method is as follows: $\mathbf{V}_{\mathbf{4}} \rightarrow \mathbf{V}_{\mathbf{3}} \rightarrow \mathbf{V}_{\mathbf{2}} \rightarrow \mathbf{V}_{\mathbf{1}}$. Now again, it is also necessary to remove cells that would early terminate the transport task. Therefore, the cell with coordinates $\left[\mathrm{V}_{1} ; \mathrm{V}_{4}\right]$ with the value of 22.1 kilometres is crossed out $[6,7,20,21]$.

Table 5. Friday - VAM - Modification 4. Source: authors

\begin{tabular}{|c|c|c|c|c|c|c|c|c|c|c|c|}
\hline & $V_{1}$ & $V_{2}$ & $V_{3}$ & $V_{4}$ & $V_{5}$ & $V_{6}$ & $V_{7}$ & & & & \\
\hline$V_{1}$ & $\mathrm{X}$ & 10.7 & 11.5 & 22.1 & 24.4 & 29.2 & 25.9 & 0.8 & 10.6 & 2.3 & 2.3 \\
\hline$V_{2}$ & 10.7 & $X$ & 1.0 & 12.0 & 14.3 & 19.0 & 15.7 & 9.7 & 1.3 & $X$ & X \\
\hline$V_{3}$ & 11.5 & 1.0 & $\mathrm{X}$ & 11.0 & 13.3 & 18.0 & 14.8 & 10.0 & $X$ & $X$ & $X$ \\
\hline$V_{4}$ & 22.2 & 11.7 & 10.7 & $\mathrm{X}$ & 4.0 & 7.9 & 4.7 & 0.7 & 0.7 & 0.7 & $X$ \\
\hline$V_{5}$ & 24.9 & 14.4 & 13.4 & 3.9 & $X$ & 7.3 & 4.7 & 0.8 & 0.8 & 0.8 & 0.8 \\
\hline$V_{6}$ & 24.7 & 14.2 & 13.3 & 3.8 & 1.9 & $\mathrm{X}$ & 4.6 & 1.9 & 1.9 & 1.9 & 1.9 \\
\hline$V_{7}$ & 26.3 & 15.8 & 14.8 & 4.8 & 4.8 & 4.2 & $X$ & 0.6 & 0.6 & 0.6 & 0.6 \\
\hline & 0.8 & 9.7 & 9.7 & 0.1 & 2.1 & 3.1 & 0.1 & & & & \\
\hline & 11.5 & $X$ & 0.8 & 0.1 & 2.1 & 3.1 & 0.1 & & & & \\
\hline & X & X & 2.6 & 0.1 & 2.1 & 3.1 & 0.1 & & & & \\
\hline & $X$ & $X$ & $X$ & 0.1 & 2.9 & 3.1 & 0.1 & & & & \\
\hline
\end{tabular}

The step which follows after further modification of the table is the calculation of the individual differences for the rows and columns of the table. The completely crossed out columns $\mathrm{V}_{1}, \mathrm{~V}_{2}, \mathrm{~V}_{3}$, as well as the rows $\mathrm{V}_{2}, \mathrm{~V}_{3}$ and $\mathrm{V}_{4}$ are omitted. Then, the highest value is taken from all the differences in the outer part of the table. This value is $3.1 \mathrm{~km}$ and is located below column $\mathrm{V}_{6}$. The resulting value is $4.2 \mathrm{~km}$, which is the lowest value of the determined column $\mathrm{V}_{6}$. This value is highlighted in yellow in the cell with coordinates $\left[\mathrm{V}_{7}\right.$; $\left.\mathrm{V}_{6}\right]$.

After finding the minimum value, it is necessary to cross out all the values in both the column and the row. Furthermore, the cell with the value of $4.6 \mathrm{~km}$ and with coordinates $\left[\mathrm{V}_{6} ; \mathrm{V}_{7}\right]$ is crossed out. This point has to be eliminated as the early closure of the distribution stations circuit could occur. The provisional route calculated using the Vogel approximation method is: $\mathbf{V}_{4} \rightarrow \mathbf{V}_{3} \rightarrow \mathbf{V}_{2} \rightarrow \mathbf{V}_{1}$ and $\mathbf{V}_{7} \rightarrow \mathbf{V}_{6}$.

Table 6. Friday - VAM - Modification 5. Source: authors

\begin{tabular}{|c|c|c|c|c|c|c|c|c|c|c|c|c|}
\hline & $V_{1}$ & $\mathbf{V}_{2}$ & $\mathbf{V}_{3}$ & $V_{4}$ & $V_{5}$ & $V_{6}$ & $V_{7}$ & & & & & \\
\hline$V_{1}$ & $\mathrm{X}$ & 10.7 & 11.5 & 22.1 & 24.4 & 29.2 & 25.9 & 0.8 & 10.6 & 2.3 & 2.3 & 2.3 \\
\hline$V_{2}$ & 10.7 & $\mathrm{X}$ & 1.0 & 12.0 & 14.3 & 19.0 & 15.7 & 9.7 & 1.3 & $X$ & $X$ & $X$ \\
\hline$V_{3}$ & 41.5 & 1.0 & $X$ & 41.0 & 13.3 & 18.0 & 14.8 & 10.0 & $X$ & X & $X$ & $X$ \\
\hline$V_{4}$ & 22.2 & 11.7 & 10.7 & $\mathrm{X}$ & 4.0 & 7.9 & 4.7 & 0.7 & 0.7 & 0.7 & $X$ & $X$ \\
\hline$V_{5}$ & 24.9 & 14.4 & 13.4 & 3.9 & $\mathrm{X}$ & 7.3 & 4.7 & 0.8 & 0.8 & 0.8 & 0.8 & 0.8 \\
\hline$V_{6}$ & 24.7 & 14.2 & 13.3 & 3.8 & 1.9 & $\mathrm{X}$ & 4.6 & 1.9 & 1.9 & 1.9 & 1.9 & 1.9 \\
\hline$V_{7}$ & 26.3 & 15.8 & 14.8 & 4.8 & 4.8 & 4.2 & $X$ & 0.6 & 0.6 & 0.6 & 0.6 & X \\
\hline & 0.8 & 9.7 & 9.7 & 0.1 & 2.1 & 3.1 & 0.1 & & & & & \\
\hline & 11.5 & X & 0.8 & 0.1 & 2.1 & 3.1 & 0.1 & & & & & \\
\hline & X & $X$ & 2.6 & 0.1 & 2.1 & 3.1 & 0.1 & & & & & \\
\hline & $X$ & $X$ & X & 0.1 & 2.9 & 3.1 & 0.1 & & & & & \\
\hline & $X$ & $X$ & $X$ & 0.1 & 22.5 & X & 21.2 & & & & & \\
\hline
\end{tabular}

The calculation is almost at the end of the transport task calculated by means of the modified Vogel approximation method. The difference between the two smallest distances in each column and row is counted, which is then written outside the table. The differences for rows $V_{2}, V_{3}, V_{4}$ and $V_{5}$ are no longer counted since the rows are completely crossed out. This is also true for columns $\mathrm{V}_{1}, \mathrm{~V}_{2}, \mathrm{~V}_{3}$ and $\mathrm{V}_{6}$. 
The highest value is sought of all the calculated differences from the outside of the table. Such a cell is in yellow and refers to column $\mathrm{V}_{5}$, from which the lowest value that is not crossed out is then selected. This is a cell with coordinates $\left[\mathrm{V}_{6} ; \mathrm{V}_{5}\right]$ with the value of $1.9 \mathrm{~km}$. The provisional sections of the route are as follows: $\mathbf{V}_{\mathbf{4}} \rightarrow \mathbf{V}_{\mathbf{3}} \rightarrow \mathbf{V}_{\mathbf{2}} \rightarrow \mathbf{V}_{\mathbf{1}}$ and $\mathbf{V}_{7}$ $\rightarrow \mathbf{V}_{\mathbf{6}} \rightarrow \mathbf{V}_{\mathbf{5}}$. In order to avoid the early termination of the transport task, we also cross out cell $\left[\mathrm{V}_{5} ; \mathrm{V}_{7}\right]$.

Table 7. Friday - VAM - Modification 6. Source: authors

\begin{tabular}{|c|c|c|c|c|c|c|c|c|c|c|c|c|}
\hline & $V_{1}$ & $V_{2}$ & $V_{3}$ & $V_{4}$ & $V_{5}$ & $V_{6}$ & $V_{7}$ & & & & & \\
\hline$V_{1}$ & $\mathrm{X}$ & 10.7 & 11.5 & 22.1 & 24.4 & 29.2 & 25.9 & 0.8 & 10.6 & 2.3 & 2.3 & 2.3 \\
\hline$V_{2}$ & 10.7 & $\mathrm{X}$ & 1.0 & 12.0 & 14.3 & 19.0 & 15.7 & 9.7 & 1.3 & $X$ & $X$ & $X$ \\
\hline$V_{3}$ & 11.5 & 1.0 & $X$ & 11.0 & 13.3 & 18.0 & 14.8 & 10.0 & $X$ & $X$ & $X$ & $X$ \\
\hline$V_{4}$ & 22.2 & 11.7 & 10.7 & $\mathrm{X}$ & 4.0 & 7.9 & 4.7 & 0.7 & 0.7 & 0.7 & $X$ & $X$ \\
\hline$V_{5}$ & 24.9 & 14.4 & 13.4 & 3.9 & $\mathrm{X}$ & 7.3 & 4.7 & 0.8 & 0.8 & 0.8 & 0.8 & 0.8 \\
\hline$V_{6}$ & 24.7 & 14.2 & 13.3 & 3.8 & 1.9 & $X$ & 4.6 & 1.9 & 1.9 & 1.9 & 1.9 & 1.9 \\
\hline$V_{7}$ & 26.3 & 15.8 & 14.8 & 4.8 & 4.8 & 4.2 & $X$ & 0.6 & 0.6 & 0.6 & 0.6 & $X$ \\
\hline & 0.8 & 9.7 & 9.7 & 0.1 & 2.1 & 3.1 & 0.1 & & & & & \\
\hline & 11.5 & $X$ & 0.8 & 0.1 & 2.1 & 3.1 & 0.1 & & & & & \\
\hline & X & $X$ & 2.6 & 0.1 & 2.1 & 3.1 & 0.1 & & & & & \\
\hline & $X$ & $X$ & X & 0.1 & 2.9 & 3.1 & 0.1 & & & & & \\
\hline & $X$ & $X$ & $X$ & 0.1 & 22.5 & X & 21.2 & & & & & \\
\hline
\end{tabular}

In the previous step, the last unnecessary cells with distance values in Friday matrix were eliminated. The last two values that were not marked or crossed out remain. In this step, these last cells are highlighted in yellow. These distance values logically complete the whole circular issue of this transport task.

It is clear from the last modification of the calculation in Table $\mathrm{X}$ that the final route of the optimized Friday route using the modified version of the Vogel approximation method is: $\mathbf{V}_{\mathbf{1}} \rightarrow \mathbf{V}_{\mathbf{7}} \rightarrow \mathbf{V}_{\mathbf{6}} \rightarrow \mathbf{V}_{\mathbf{5}} \rightarrow \mathbf{V}_{\mathbf{4}} \rightarrow \mathbf{V}_{\mathbf{3}} \rightarrow \mathbf{V}_{\mathbf{2}} \rightarrow \mathbf{V}_{\mathbf{1}}$. The resulting length of the route is 25.9 $+4.2+1.9+3.9+10.7+1.0+10.37=58.3 \mathrm{~km}$.

The original length of Friday route was $64.9 \mathrm{~km}$. The newly created route optimized by the Vogel approximation method is $58.3 \mathrm{~km}$. This will shorten the route by $6.6 \mathrm{~km}$. The original and optimized route composition is shown in Table $8[22,23]$.

Table 8. Friday - Measure proposals. Source: authors

\begin{tabular}{|c|l|l|l|l|l|l|l|l|l|}
\hline Current: & $\mathrm{V}_{1}$ & $\mathrm{~V}_{2}$ & $\mathrm{~V}_{3}$ & $\mathrm{~V}_{4}$ & $\mathrm{~V}_{5}$ & $\mathrm{~V}_{6}$ & $\mathrm{~V}_{7}$ & $\mathrm{~V}_{1}$ & $\mathbf{6 4 . 9} \mathbf{~ k m}$ \\
\hline Optimized: & $\mathrm{V}_{1}$ & $\mathrm{~V}_{7}$ & $\mathrm{~V}_{6}$ & $\mathrm{~V}_{5}$ & $\mathrm{~V}_{4}$ & $\mathrm{~V}_{3}$ & $\mathrm{~V}_{2}$ & $\mathrm{~V}_{1}$ & $\mathbf{5 8 . 3} \mathbf{~ k m}$ \\
\hline
\end{tabular}

As the number of travelled kilometres is reduced, transport-logistic costs will also be reduced as shown in Table 9. The table shows an annual cost savings of 983 CZK.

Table 9. Friday - Economic indicators. Source: authors

\begin{tabular}{|c|c|c|c|}
\hline Route & $\begin{array}{c}\text { Costs per 1 travel } \\
\text { [CZK] }\end{array}$ & Annual costs [CZK] & $\begin{array}{c}\text { Difference of } \\
\text { annual costs } \\
\text { versus current } \\
\text { route [CZK] }\end{array}$ \\
\hline Current & 193.19 & 9,660 & \\
\hline Opti.-VAM & 173.54 & 8,677 & -983 \\
\hline
\end{tabular}

For a better visual idea, the new route is shown on the map in Figure 1. The light blue route represents the original route. The new distribution circuit is pink. In places where the original and new routes overlap the colour is purple. 


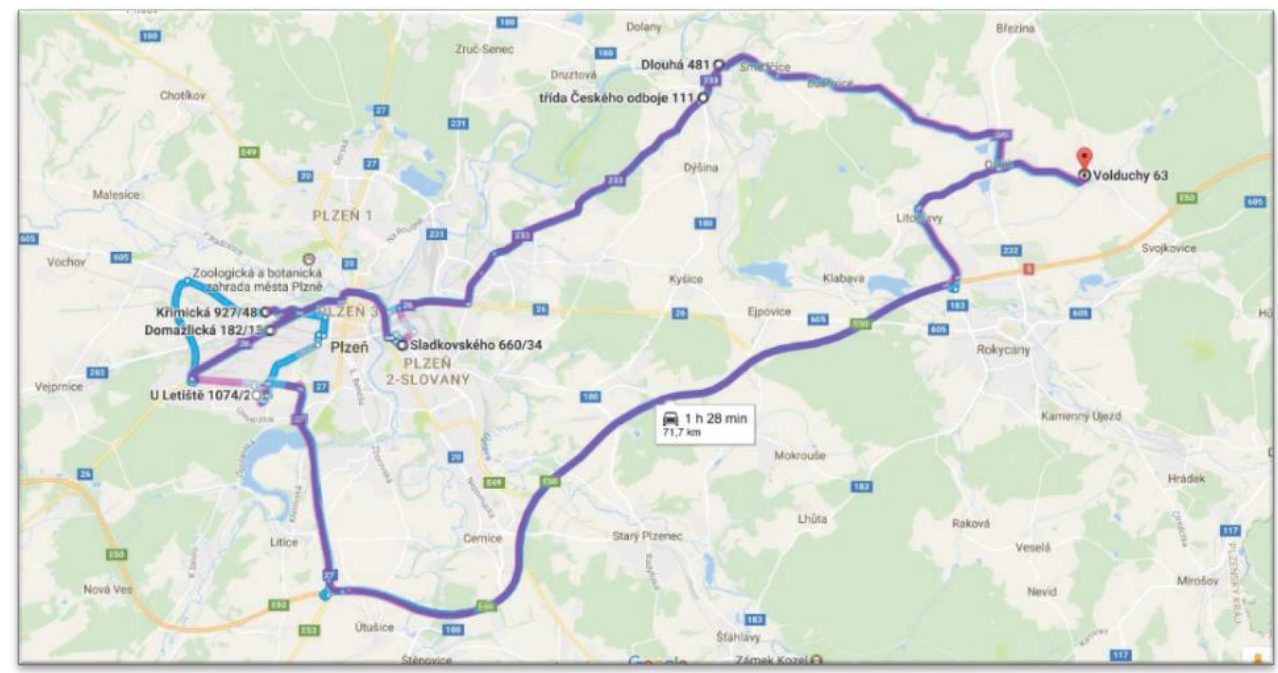

Fig. 1. Comparison - Friday route. Source: authors

\section{Conclusion}

The goal of the Vogel approximation method was to reduce the operating costs of transport in a selected company. Since it is a small family business, the transport is carried out by Volkswagen Transporter. In order to achieve desired results, it was necessary to create a list of delivery routes for each working day of the week with the company owner. Subsequently, Friday route was selected for implementation of the method due to the least number of stops. On the basis of Friday delivery results, the Vogel approximation method will apply to all delivery routes.

It has been confirmed that using operational research can really improve transportlogistic processes in the selected company. According to the economic evaluation, annual costs may be reduced and the total number of travelled kilometres has been decreased.

This paper is supported by the research project "From horse-drawn railway to intermodal transport" within Visegrad Fund.

\section{References}

1. N. Ganikhodjaev, S.F. Zakaria, International Conference on Operations Research and Statistics, 111-116 (Singapore: Global Science and Technology Forum, 2011)

2. S. Kurian, H.N. Ramanathan, P.S. Chacko, Journal of Supply Chain Management Systems 2, 4, 13-19 (2013)

3. J. Fotr, Tvorba strategie a strategické plánování: teorie a praxe (Grada, Prague, Czech Republic, 2012)

4. J. Široký, et al., Technologie dopravy (University of Pardubice, Czech Republic, 2014)

5. O. Stopka, M. Chovancová, J. Ližbetin, V. Klapita, Nase More 63, 3, 195-199 (2016), DOI: $10.17818 / \mathrm{NM} / 2016 / \mathrm{SI} 22$ 
6. M. Weiszer, G. Fedorko, V. Molnar, CLC 2013 - Carpathian Logistics Congress, 330-335 (Krakow, Poland, 2104)

7. L. Bartuška, J. Čejka, Z. Caha, Nase More 62, 91-96 (2015)

8. J. Jablonský, Operační výzkum: kvantitativní modely pro ekonomické rozhodování (Professional Publishing, Prague, Czech Republic, 2007)

9. R. Sen, P. Rathindra, Operations research: Algorithms and Applications (Rekha Printing Pvt, New Delhi, India, 2012)

10. P. Fiala, et al., Operační výzkum: nové trendy (Professional Publishing, Prague, Czech Republic, 2010)

11. L. Bartuška, O. Stopka, J. Ližbetin, Transport Means - 19th International Scientific Conference on Transport Means, 215-218 (Kaunas: Kaunas University of Technology, Lithuania, 2015)

12. F.S. Hillier, G.J. Lieberman, N. Bodhibrata, B. Preetam, Introduction to operations research (Mathematics in science and engineering, New Delhi, India, 2014)

13. N.K. Tiwari, K. Shandilya Shishir, Operations research (PHI Learning, New Delhi, India, 2006)

14. O. Stopka, I. Simkova, Transport and Telecommunication Journal 16, 4, 320-329 (2015), DOI: 10.1515/ttj-2015-0029

15. J. Štůsek, Ǩizení provozu v logistických řetězcích (C.H. Beck, Prague, Czech Republic, 2007)

16. T. Klieštik, Transport Means - 17th International Conference on Transport Means, 308-311 (Kaunas: Kaunas University of Technology, Lithuania, 2013)

17. V. Klapita, Logi - Scientific Journal on Transport and Logistics, 3, 2, 57-64 (2012)

18. O. Stopka, B. Sarkan, M. Chovancova, L.M. Kapustina, Communications: Scientific Letters of the University of Zilina 19, 2, 18-22 (2017)

19. J. Široký, Transport technology and control (Librix.eu, Brno, Czech Republic, 2014)

20. R. Kampf, J. Cejka, M. Telecky, Communications: Scientific Letters of the University of Zilina 18, 2, 129-132 (2016)

21. G. Fedorko, H. Neradilova, M. Sutak, V. Molnar, Transport Means - 20th International Scientific Conference on Transport Means, 169-174 (Juodkrante, Lithuania, 2016)

22. M. Chovancová, V. Klapita, Open Engineering 7, 1, 50-54 (2017), DOI: 10.1515/eng2017-0009

23. F. Meszaros, R. Markovits-Somogyi, Z. Bokor, Logi - Scientific Journal on Transport and Logistics 3, 1, 70-82 (2012) 